\title{
MENGEMBANGKAN KEMAMPUAN MEMBACA ANAK USIA DINI DENGAN MULTIMEDIA INTERAKTIF
}

\author{
Priawan Ardi Putra ${ }^{\text {a, }}$ Isabella Hasiana ${ }^{\text {b }}$ \\ ${ }^{a}$ Universitas PGRI Adi Buana Surabaya \\ ${ }^{\mathrm{b}}$ Universitas PGRI Adi Buana Surabaya \\ e-mail korespondensi: priawanardiputra@gmail.com
}

\begin{abstract}
This research is motivated by the fact that learning still uses conventional learning. The media used is still using books or student worksheets. This causes teaching and learning activities for children to become bored and less varied. This is due to the lack of teacher media to convey learning to students. So that teachers prefer to use media that is easy and sober so that the development of children's reading skills has not yet developed optimally

The aim of this research is to find out the effect of interactive multimedia on children's reading ability. The method used in this research is quantitative Pre Experimental with the design of "the one group pretest posttest". The sample in this study were 18 children in group A Kindergarten consisting of 10 male students and 8 female students. The data collection technique used is the method of observation and documentation. The results of the analysis show that the t test results Sig $(0,000)<0.05$ means there is an influence. This means that interactive multimedia affects the reading of group A children.
\end{abstract}

Keywords: early childhood, Interactive Multimedia, and Reading Ability

\section{PENDAHULUAN}

Anak usia dini atau usia 0-8 tahun merupakan satu bagian dari periode sensitif yang dialami oleh seorang anak. Pada periode ini anak mengalami masa keemasan di mana otak tumbuh dengan sangat pesat. Oleh karena itu periode ini harus dimanfaatkan seoptimal mungkin dengan mengkondisikan anak dalam situasi pembelajaran yang disesuaikan dengan dunia anak, yaitu memberikan kesempatan kepada anak untuk aktif dan kreatif dengan menerapkan konsep belajar sambil bermain dan bermain seraya belajar (Partini 2015:96).

Undang-Undang Republik Indonesia No 20 tahun 2003 Bab 1, pasal 1, butir 14, tentang Sistem Pendidikan Nasional, menegaskan bahwa: "Pendidikan anak usia dini adalah suatu upaya pembinaan yang ditujukan kepada anak sejak lahir sampai dengan usia enam tahun yang dilakukan melalui pemberian rangsangan pendidikan untuk membantu pertumbuhan dan perkembangan jasmani dan rohani agar anak memiliki kesiapan dalam memasuki pendidikan lebih lanjut". Pendidikan TK (Taman Kanak-kanak) bukan kewajiban. Namun, apabila memaknai lebih 
mendalam tentang pentingnya pendidikan sejak usia dini, maka pendidikan TK atau prasekolah merupakan bentuk pendidikan yang sangat penting bagi kehidupan manusia dimasa mendatang. Pendidikan anak usia dini (PAUD) merupakan tahapan yang sangat fundamental bagi perkembangan dan pendidikan selanjutnya. Dalam usia ini merupakan masa emas sekaligus masa kritis dalam tahapan kehidupan manusia yang akan menentukan perkembangan selanjutnya. Dikatakan masa emas karena pada masa ini adalah saat paling baik untuk mengoptimalkan seluruh aspek-aspek perkembangan anak, dan anak bagaikan "spons" yang akan menyerap sebanyak-banyaknya informasi dari lingkungannya. Sedangkan dikatakan masa kritis karena pada usia tersebut anak, anak masih sangat rentan sehingga apabila penanganan yang diberikan atau dilakukan terhadap anak tidak tepat maka hal tersebut akan dapat merugikan anak itu sendiri dan dapat berakibat kurang baik bagi kehidupannya dimasa mendatang. Selain itu, pada masa ini juga disebut masa peka atau masa sensitif. Masa sensitif adalah masa terjadinya kematangan fungsi fisik dan psikis yang siap merespon stimulasi yang diberika oleh lingkungan. Masa peka pada setiap anak berbedabeda, seiring dengan laju pertumbuhan dan perkembangan anak secara individual, Widarmi dkk (2014:X).

Di sisi lain terdapat fakta dalam proses pembelajaran di PAUD bahwa muncul banyak permasalahan. Permasalahan tersebut meliputi semua pengembangan kemampuan dasar dan pembiasaan di PAUD yaitu sikap perilaku yang meliputi moral agama, sosial emosional, kemandirian, dan kemampuan dasar yang mencakup kemampuan bahasa, kognitif, fisik motorik, dan seni (Partini 2015:96).

Aspek perkembangan bahasa memiliki peranan penting dalam pertumbuhan dan perkembangan anak. Hal ini dikarenakan bahasa merupakan alat komunikasi,yang mencakup semua cara berkomunikasi sehingga pikiran dan perasaan dapat dinyatakan dalam bentuk tulisan, lisan, isyarat atau gerak dengan menggunakan kata-kata, kalimat, bunyi, lambang, dan gambar (Mulyasa 2014:27).

Kemampuan berbahasa ada empat macam, yaitu membaca, menulis, menyimak, dan berbicara. Menurut Tarigan (2008: 7), membaca adalah proses yang dilakukan serta digunakan oleh pembaca untuk memperoleh pesan, yang hendak disampaikan oleh penulis melalui bahasa tulis. Pada kemempuan berbahasa khususnya membaca, jika di stimulasi sejak anak usia dini dengan cara belajar melalui bermain dan menggunakan prisnsip pembelajaran anak usia dini maka kemampuan membaca anak akan berkembang sesuai tahapan usianya.

Leonhardt (dalam Nurbiana 2008:5.4) mengungkapkan bahwa membaca sangatlah penting untuk distimulus bagi anak. Anak-anak yang gemar membaca akan mempunyai rasa kebahasaan yang lebih tinggi. Kegemaran membaca harus dikembangkan sejak dini. Sejalan dengan pendapat ini Montessori dan Hainstock mengemukakan bahwa pada usia 4-5 tahun anak sudah bisa diajarkan membaca. Bahkan membaca merupakan permainan yang menyenangkan bagi anak usia ini. Oleh karena itu, berdasarkan pendapat di atas, kemampuan membaca sudah dapat dikembangkan di TK. Seperti yang 
dikemukakan oleh Moleong (2013:25) salah satu aspek kemampuan yang harus dikembangkan anak TK adalah kemampuan membaca. Dengan dibiasakannya belajar membaca sejak dini, maka anak akan memperoleh informasi yang lebih banyak dari apa yang telah dibacanya

Anak usia dini suka bermain, aktif, dan selalu ingin tahu. Oleh karena itu, kegiatan pembelajaran dirancang agar anak dapat belajar sambil bermain (Susanto 2017:21). Hal ini disampaikan juga oleh (Usman 2002:196) yang mengatakan bahwa anak usia dini, belajar adalah bermain, dan bermain adalah belajar. Jadi dalam empat macam kemampuan berbahasa tidak terkecuali dalam kemampuan membaca akan merasa senang dan nyaman belajar apabila menggunakan metode yang menyenangkan dengan cara bermain

Pada kenyataannya media yang dipergunakan dalam kegiatan belajar mengajar, seiring dengan perkembangannya ilmu pengetahuan dan teknologi, banyak sekali media pembelajaran yang dapat dipergunakan untuk membantu seorang guru dalam menyampaikan materi pembelajaran, seperti media dengan menggunakan majalah, buku, lembar kerja siswa, atau juga media elektronika seperti radio, televisi, dan lainnya. Media yang ada di sekolah pada umumnya masih bersifat konvensional. Dalam arti lain media yang di gunakan masih menggunakan buku atau lembar kerja siswa (LKS). Hal ini menyebabkan kegiatan belajar mengajar untuk anak menjadi jenuh dan kurang bervariasi. Hal ini didapatkan penulis saat melakukan observasi awalpada anak kelompok A yang proses belajar mengajarnya masih menggunakan media LKS dan buku-buku.
Salah satu strategi yang dapat di gunakan untuk menarik perhatian anak yaitu dengan media pembelajaran yang menarik. Media pembelajaran mempunyai peranan yang penting dalam kegiatan belajar mengajar. Media pembelajaran juga merupakan alat bantu yang memudahkan guru untuk menyampaikan materi pembelajaran kepada siswa. Media yang digunakan harus interaktif agar anak tidak merasa jenuh ketika kegiatan pembelajaran. Menurut Asmoro (2019:9) Multimedia interaktif dapat mengubah proses belajar mengajar konvensional menjadi lebih interaktif. Sehingga anak usia dini aka tertarik melakukan kegiatan belajar mengajar khusunya dalam pembelajaran membaca.

Multimedia interaktif yaitu jenis media yang memanfaatkan komputer dalam pembuatan dan penggabungan dari bagian tulisan, gambar, suara, video dan animasi yang dapat membuat pengguna dapat menggunakan atau berhubungan baik (Asmoro 2019:3). Kemampuan media ini dianggap lebih baik dan lebih menarik sebab mengandung berbagai unsur jenis media. Kelebihan ini yang menyebabkan multimedia interaktif lebih aktif dan menyenangkan bagi penggunaanya, sehingga dapat menghilangkan kejenuhan dan membuat pembelajaran menjadi tidak monoton.

Dari permasalahan tersebut, dan mengingat pentingnya pengembangan bahasa anak usia dini terutama pada kemampuan membaca maka penulis tertarik untuk melakukan penelitian lebih mendalam dan menuangkannya dalam sebuah judul penelitian "Mengembangkan Kemampuan Membaca Anak Usia Dini Dengan Multimedia Interaktif" 
Tabel 1. Paired Samples Test

\begin{tabular}{lllll}
\hline & & N & $\begin{array}{l}\text { Corre } \\
\text { lation }\end{array}$ & Sig. \\
& Pre Test & & & \\
Pair 1 & \& Post & 18 & .759 & .000 \\
& Test & & & \\
\hline
\end{tabular}

Tabel 1. Paired Samples Test

\begin{tabular}{lllll}
\hline & & N & Corre & Sig. \\
& & & \\
& lation & \\
\hline \multirow{3}{*}{ Pair 1 } & Pre Test & & & \\
& \& Post & 18 & .759 & .000 \\
& Test & & & \\
\hline
\end{tabular}

\section{METODE PENELITIAN}

Penelitian ini merupakan pendekatan penelitian kuantitatif dengan desain PreEksperimental One Group Pretest-Posttest Design (Sugiyono, 2016:109-110).

Sampel yang diteliti pada penelitian ini adalah seluruh anak kelompok A yang sebanyak 18 peserta didik.

Pengumpulan data menggunakan instrumen lembar observasi yang digunakan untuk mengamati kinerja (unjuk kerja) anak baik pada saat pre-test, proses kegiatan maupun post-test. Observasi dilakukan berdasarkan rubrik observasi dan 3 (tiga) indikator yang sudah ditetapkan. Ketiga indikator tersebut adalah: a) mengenal pembendaharaan kata; b) memperkaya pembendaharaan kata; c) meniru (menulis dan mengucap huruf A-Z). Sedangkan untuk menganalisis data dan menguji hipotesis digunakan uji statistik sesuai dengan rancangan penelitian. Teknik analisis data yang diterapkan adalah uji t.

\section{HASIL PENELITIAN}

Data hasil penelitian ini dapat dideskripsikan pada tabel berikut

Penguji statistik pada penelitian ini untuk menguji apakah multimedia interaktif berpengaruh terhadap kemampuan membaca anak kelompok A. Penguji hipotesis adalah untuk menentukan apakah hipotesis 0 diterima atau tidak.

Uji Hipotesis : Jika nilai Sig. $<0,05$ maka ada pengaruh antaramultimedia interaktif dengan kemampuan membaca anak. Jika nilai Sig. > 0,05 maka tidak ada pengaruh antara multimedia interaktif dengan kemampuan membaca anak.

Berdasarkan tabel diatas, menunjukkan hasil penelitian dengan hasil hitung uji t Sig $(0,000)<$ 0,05 berarti ada pengaruh antara multimedia interaktif terhadap kemampuan membaca anak kelompok A

\section{PEMBAHASAN}

Hasil penelitian dengan hasil hitung uji t Sig $(0,000)<0,05$ berarti ada pengaruh antara multimedia interaktif terhadap kemampuan membaca anak kelompok A.

Dari data yang dikumpulkan dari hasil pre-test untuk mengetahui pengaruh multimedia interaktif terhadap kemampuan membaca anak kelompok A menunjukkan, dari 3 indikator yang diteliti pada 18 anak belum ada yang berkembang sangat baik, dikarenakan anak kelompok A ini belum mengerti kata yang dia terima dan belum adanya media yang membuat anak tertarik untuk belajar membaca 
sehinga menjadi faktor kurangnya kemampuan membaca anak kelompok A.

Anak usia TK (kelompok A) yang berusia 4-5 tahun, anak mulai tertarik dengan berbagai huruf atau bacaan yang ada gambarnya dalam ukuran besar, kemudian anak mulai mengeja huruf serta membacanya. Untuk mengoptimalkan kemampuan mambaca anak ada tahap ini, dapat disediakan sebagai gambar yang disertai tulisan dengan ukuran yang besar, kemudian ajak anak untuk membaca tulisan dengan cara mengeja.

Suyanto (2005:168) mengatakan saat anak berusia lima tahun. Pada tahap ini anak mulai sadar akan fungsi bacaan dan cara membacanya. Anak tertarik dengan berbagai bacaan yang ada gambarnya, dan anak mulai mengeja dan membaca kata.

Setelah diberikan perlakuan berupa multimedia interaktif dapat diketahui ada pengaruh terahadap kemampuan membaca anak. Hal ini dapat dilihat dari kemampuan membaca anak Kelompok A mengalami peningkatan. Anak sudah mampu mengucapkan huruf A-Z dengan baik dan juga tanpa arahan dari guru. Dengan adanya multimedia interaktif ini anak lebih antusias untuk melakukan kegiatan belajar mengajar dan anak merasa lebih menyenangkan dengan pembelajaran menggunakan multimedia interaktif.

Menurut Singer (dalam Kurnia, 2012:2), mengemukakan bahwa bermain dapat digunakan anak-anak untuk menjelajahi dunianya, mengembangkan kompetensi dalam usaha mengatasi dunianya dan mengembangkan kreativitas anak. Dengan bermain anak memiliki kemampuan untuk memahami konsep secara ilmiah, tanpa paksaan.
Menurut Asmoro (2019:9) Multimedia interaktif dapat mengubah proses belajar mengajar konvensional menjadi lebih interaktif. Maka anak usia dini aka tertarik melakukan kegiatan belajar mengajar khusunya dalam pembelajaran membaca. Sehingga kemampuan membaca anak usia dini mengalami perkembangan yang baik.

Sejalan dengan itu selain multimedia interaktif juga memperhatikan karakteristik anak yang suka bemain atau sesuatu yang menyenangkan. Dengan media yang menyenangkan sepeti multimedia interaktif yang di dukung dengan visual, audio, dan audio-visual, menjadikan dapat melakukan aktifitas bermain dengan sendirinya.

Dalam proses penelitian di lapangan anak lebih besemangat dalam pembelajaran saat menggunakan multimedia interaktif, karena multimedia interaktif menyajikan pemainan yang menyenangkan dan didukung dengan animasi gambar yang menarik.

Diperkuat oleh pendapat Shofi (2008:38) bahwa metode game (pemainan) yang sangat mengasikkan dan dapat di jadikan sebagai sarana untuk mengasah otak anak. Permainan interaktif dapat digunakan dalam metode ini.

Dari pembahasan diatas dapat disimpulkan bahwa multimedia interaktif berpengaruh terhadap kemampuan membaca anak kelompok A, karena dengan pembelajaran menggunakan multimedia interaktif anak lebih antusias untuk melakukan kegiatan belajar mengajar dan anak merasa lebih menyenangkan dengan pembelajaran menggunakan multimedia interaktif, sehingga perkembangan kemampuan membaca anak berkembang dengan baik. 


\section{SIMPULAN DAN SARAN}

\subsection{Simpulan}

Berdasarkan hasil pengujian dan pembahasan hasil penelitian ini, dapat disimpulkan bahwa ada "Pengaruh Multimedia Interaktif Terhadap Kemampuan Membaca Anak Kelompok A”.

Penelitian ini berjalan dengan baik dan membawa dampak yang sangat baik bagi perkembangan kemampuan membaca anak. Dibawah ini beberapasaran yang diharapkan dapat menjadi sebuah bahan pertimbangan bagi pihak-pihak terkait dalam dunia pendidikan anak usia dini.

\subsection{Saran}

Berdasarkan simpulan tersebut, saran yang dapat diberikan oleh peneliti kepada beberapa pihak sebagai berikut:

1. Bagi anak didik, meningkatkan minat anak dalam pembelajaran membaca.

2. Bagi guru, memberikan pengetahuan dalam melaksanakan kegiatan pembelajaran yang menyenangkan, terutama dalam mengembangkan kemampuan membaca melalui multimedia interaktif.

3. Bagi peneliti selanjutnya, diharapkan dapat memberikan manfaat dan dijadikan masukan dan acuan untuk melakukan penelitian lebih lanjut dalam mengkaji masalah-masalah yang sama.

\section{REFERENSI}

Asmoro Siwi Widi. 2019. Desain Media Interaktif (Kopetensi Keahlian Multimedia). Jakarta: PT Bumi Aksara.

Kurnia, Rita. 2012. "Konsepsi Bermain dalam Menumbuhkan Kreativitas Pada Anak Usia Dini”. EDUCHILD, Vol. 01, No. 1: 2.
Moleong, Lexy J. 2003. Metode Penelitian Kualitatif. Bandung : PT. Remaja Rosdakarya

Mulyasa. 2014. Manajemen PAUD. Bandung: PT. Remaja Rosdakarya.

Nurbiana, dkk. 2008. Metode pengembangan bahasa. Jakarta : Pusat Penerbitan Universitas Terbuka

Partini. 2015. Upaya Meningkatkan Kemampuan Kerjasama Melalui Metode Proyek Pada Anak. Universitas Slamet Riyadi Surakarta.

Shofi, Ummu. 2008. Sayang, Belajar Baca Yuk!. Solo: Indiva Media Kreasi

Sugiyono. 2016. Metode Penelitian Pendidikan Pendidikan Pendekatan Kuantitatif, Kualitatif, dan $R \& D$. Bandung: Alfabeta.

Susanto, Ahmad. 2017. Pendidikan Anak Usia Dini (Konsep dan Teori). Jakarta: PT Bumi Aksara.

Suyanto, 2005. Konsep Dasar Anak Usia Dini : Jakarta : Departemen Pendidikan Nasional Shofi, Ummu. 2008. Sayang, Belajar Baca Yuk!. Solo: Indiva Media Kreasi

Tarigan. 2008. Membaca. Bandung: Angkasa

Usman. 2002. Media Pendidikan. Jakarta: Ciputat 